\title{
検像システムに求められる機能要件の実態調査
}

\author{
横岡由姫 ${ }^{1,2}$ 奥田保男 ${ }^{3}$ 坂本 $\quad$ 博 ${ }^{4,5}$ 井原完有 ${ }^{6}$ 川眞田実 ${ }^{7}$ 山田英司 ${ }^{8}$
}

\author{
${ }^{1}$ 量子科学技術研究開発機構放射線医学総合研究所臨床研究クラス夕病院医療情報室 \\ 2 千葉大学大学院医学薬学府先端医学薬学専攻 \\ 3 量子科学技術研究開発機構放射線医学総合研究所研究企画室 \\ ${ }^{4}$ 東北大学病院診療技術部放射線部門 \\ ${ }^{5}$ 東北大学病院メディカル IT センター
}

(現 東北大学病院診療技術部放射線部門)

${ }^{6}$ 国立がん研究センター中央病院放射線技術部放射線診断技術室

${ }^{7}$ 大阪府立成人病センター放射線診断科

(現 大阪国際がんセンター放射線診断・IVR 科)

8 大阪市立大学医学部附属病院中央放射線部

緒 言

近年, 画像診断はフィルムから電子的な画像による
モニ夕診断へと移行している。電子的な利点を活かし た画像保存だけでなく, 画像交換や大規模な情報共有

\section{Survey of the Requested Function for Quality Assurance System for Images (Kenzo System)}

Yuki Yokooka, ${ }^{1,2 *}$ Yasuo Okuda, ${ }^{3}$ Hiroshi Sakamoto, ${ }^{4,5}$ Kanyuu Ihara, ${ }^{6}$ Minoru Kawamata, ${ }^{7}$ and Eiji Yamada ${ }^{8}$

${ }^{1}$ Department of Medical Informatics Section, National Institute of Radiological Sciences Hospital, National Institutes for Quantum and Radiological Science and Technology

2 Graduate School of Medical and Pharmaceutical Science, Chiba University

${ }^{3}$ Department of Research Planning and Promotion Office, National Institute of Radiological Sciences, National Institutes for Quantum and Radiological Science and Technology

${ }_{5}^{4}$ Clinical Technology Department of Radiology, Tohoku University Hospital

${ }^{5}$ Medical IT Center, Tohoku University Hospital

(Current address: Clinical Technology Department of Radiology, Tohoku University Hospital)

${ }^{6}$ Department of Radiological Technology, Radiological Diagnosis, National Cancer Center Hospital

${ }^{7}$ Department of Diagnostic Radiology, Osaka Medical Center for Cancer and Cardiovascular Diseases

(Current address: Department of Diagnostic and Interventional Radiology, Osaka International Cancer Institute)

${ }^{8}$ Department of Central Radiology, Osaka City University Hospital

Received January 13, 2017; Revision accepted April 9, 2018

Code No. 1060

\section{Summary}

As the use of filmless examination images, using various systems, has increased, and became common to perform KAKUTEI and save the images. In particular, the use of quality assurance system for images (Kenzo system) has increased to ensure the efficient performance of confirmed image. However, there has been no report showing what kind of function should be used or how to write the specifications of such a function in introducing the Kenzo system. Therefore, this study conducted a survey to the in-charge medical staff of medical institutions to provide "information included in the specifications when introducing medical systems". As a result, it is possible, through analyzing and clarifying the necessary functions of the Kenzo system, to apply it in medical institutions with various scales and workflows. The results indicate the person in charge was looking for functions, such as "coordination of information and image processing, securing the consistency of the information, and clarifying responsibility using the records of confirmed persons". We showed examples of how to describe these in the specifications.

Key words: confirming image (KAKUTEI), quality assurance system for images (Kenzo system), introduction, quality control, requested functions

*Proceeding author 
なども実現可能となっている。実際「電子カルテ\& PACS 白書 2013〜2014」 のアンケートでは，約 86\% の施設が「picture archiving communication system (PACS)が稼働している，または開発中である」と回 答した，電子化への移行に伴い，診療現場での業務フ ローやプロセスもシステムの利用へと変化している。 画像の確認や修正などの検像行為は, モダリティのコ ンソール上だけでなく，検像システムを利用して行う 方法がある。検像システムは, モダリティから送信さ れた画像データに対して濃度などの調整を行う画質処 理やシリーズの分割, 画像格納順の並び替え, 患者情 報の確認・修正などを容易に行うことができ，作業の 効率化㧍よび画質の担保が可能となる2,3)，検像行為 の手順は施設ごとにさまざまであるため, 個々の業務 フローに沿った検像システムの導入を検討する施設 は, 今後更に増加すると考えられる。新田ら ${ }^{4)}$ は,「放 射線画像の quality control を行い, 画像参照に余計な 負担を掛けないこと」を達成するために, 2000 年頃に 検像システムを開発し，アノテーションや画像の削 除, 画像パラメータの変更などの機能が利用されてい た，その後，検像システムを導入したユーザが，自施 設のワークフローやポリシーを検討しながら検像シス テム構築を行うようになった。例えば松田 ${ }^{5}$, 山田 $ら^{6,7)}$ は, フィルムレス環境下に扔ける検像行為につ いて検討し，ワークフローを改善して一般撮影などに 検像システムを導入開発した。井原ら ${ }^{8.9)}$ は, 他シス テムからの検査依頼情報を検像システム上で取得, 表 示し, 検查情報・患者情報・実施情報の整合性を担保 するシステムを開発した。このように, 各施設におけ る機能実装や工夫手法の報告があるものの, 多施設に おいて導入時に検討した機能や問題点, 導入に伴う業 務フローの変化などを体系的に集約した報告はなく， 各施設が独自に調查していたのが現状である。そのた め, 十分な情報がない状況で導入を進めた場合, シス テム導入後の改修とトラブル対応などに時間を要する ことが考えられる。笠原の報告 ${ }^{10)}$ では「最新情報の 意見交換会的な役割, ユーザ主体の情報交換の場, 最 新の技術や情報の共有を期待する」との回答が多いこ とから, 院内で診療放射線技師(技師) 業務を行いなが らシステム管理も担当している会員は, システムの導 入と利用に関する情報を求めていることが明らかに なっている. 更に, 隅田 ${ }^{11)}$ が行ったアンケート調査の 結果に扮いても「ハード・ソフトウエアを含めたシス テムの運用と管理に関する情報や，システム構築例」 などの情報が求められていることが示された，前述の ように, 日本放射線技術学会医療情報分科会が発足し
た当時 ${ }^{12)}$ から現在まで継続して，医療情報システムに 関する基礎知識や情報提供, 導入事例の報告がなされ ている ${ }^{13)}$. しかし，これまでに検像システムに関する 導入状況や各施設での業務環境, 必要とされる機能な どについて，多施設を対象に体系的に調査した報告は 行われていない，そこで本研究では，医療機関からの アンケートにより得られた検像システムに必要とされ る機能を分析することで, 医療機関の規模や業務フ ローなどを考慮しつつ, 検像システム導入のための仕 様書に記載すべき情報の提案を目的とした。

\section{1. 方 法}

\section{1-1 アンケートの対象}

日本放射線技術学会の了承を得て，医療情報分科会 (現 医療情報部会) 会員のうち, 会員登録時にメール アドレスを登録していなかった 138 施設に対して，回 答用紙と返信用封筒を同封したアンケートの依頼文を 郵送した。メールアドレスを登録していた会員と日本 放射線技術学会のメールマガジンに登録している会員 に対し, 回答専用 web 入力フォームの uniform resource locator (URL)を記述したアンケートの依頼文 を送信した。アンケート調查は，平成 25 年 10 月 3 日 から平成 25 年 11 月 1 日に行い表計算ソフトウェア Excel(Microsoft 社)を用いて集計した。

\section{1-2 アンケート質問項目の内容}

質問項目は全 22 項目であったが, 質問 3 は任意の 項目であること，質問 13,14 は質問内容に曖昧な点が あり十分な回答を得ることができなかったために分析 対象から除外し, 全 19 項目とした。詳細な質問項目 について, 以下に示す.

(1) 回答者の属性に関する質問

質問 1 : 所属施設の所在地, 質問 $2:$ 所属施設の種 別, 質問 4 : 病床数, 質問 5 : 職種, 質問 6 : 外来数, 質問 7 : 技師数, 質問 8 :「画像情報の確定に関する ガイドライン $\rfloor^{14,15)}$ の読了状況.

(2) 回答者施設に扔ける, 検像システムの利用状況 質問 9: フィルムレス運用を行っているモダリティ, 質問 10 : 所有しているモダリティ数, 質問 11 : 各モ ダリティの 1 日あたりの検査数, 質問 12 : 検像シス テムを利用しているモダリティの種別, 質問 15 ：検 像システムの導入経緯, 質問 16 : 検像行為を行う夕 イミングについて, 質問 17 : 検像行為を行う担当者 について, 質問 18 : 検像行為を行う専任者の技師 歴, 質問 19 : 検像システムを導入した際に新たに追 加した機能とその理由, 質問 20 : 導入済みの検像シ 


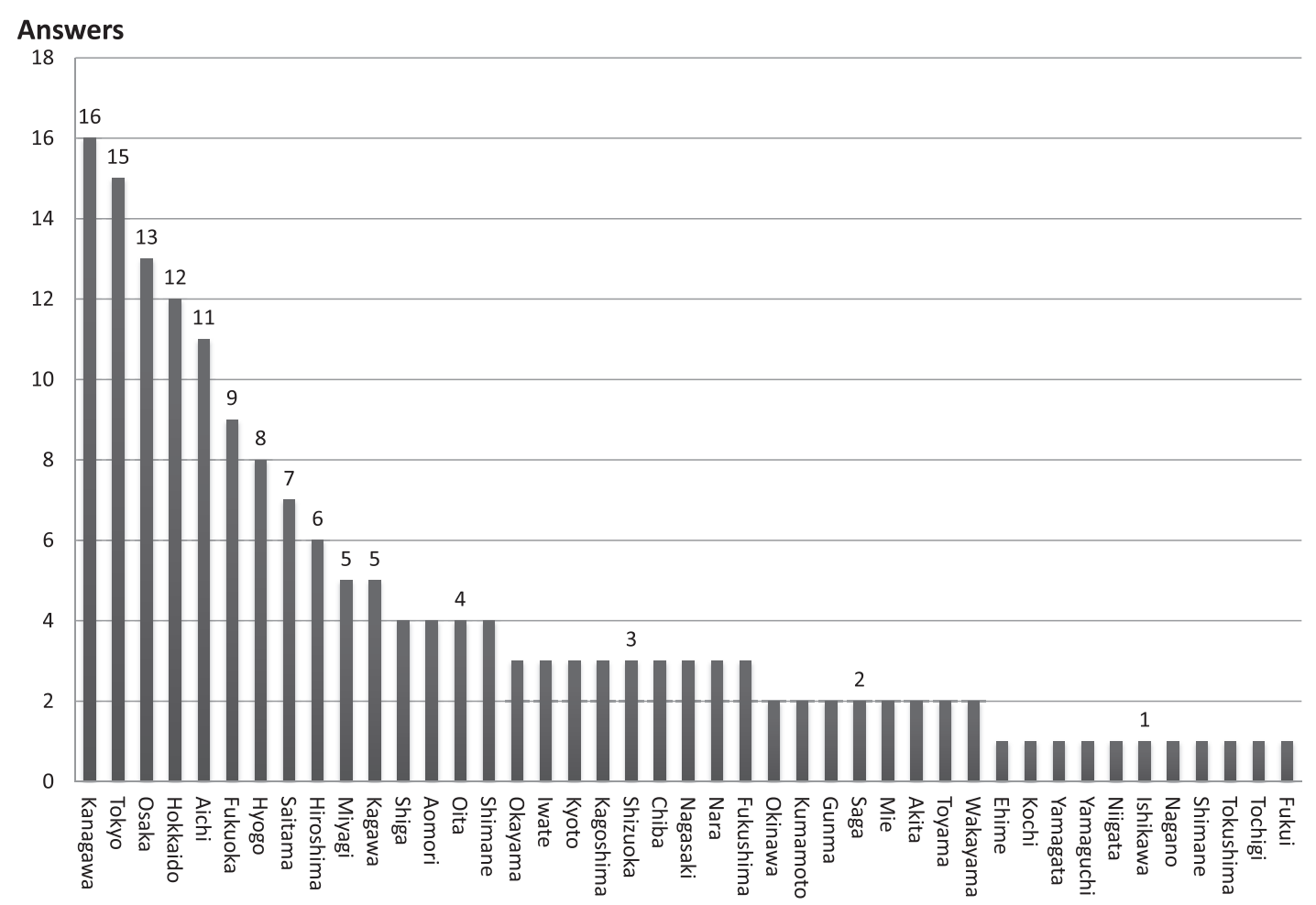

\section{Prefecture}

Fig. 1 Number of responses for each prefecture.

ステムに関する問題点, 質問 21 : 検像システムを導 入できない，または導入しない理由, 質問 22 : 本研 究に対する意見.

\section{2. 結 果}

総回答数は 188 回答で, うち有効回答数は 177 回答 であった．無効回答を 11 回答 (1 施設から複数回答が あったもの 6 回答, 回答不十分が 5 回答) とした。な お, 本研究の解析対象は有効回答のみとした。

2-1 回答者の属性（質問 1〜質問 8, ただし質問 3 を 除<)

都道府県別では神奈川県が一番多く16 回答，次い で東京都が 15 回答であった (Fig. 1). 所属施設の種 別では公立機関が 41 回答と一番多く，医療法人が 38 回答, 大学病院が 27 回答であった (Table 1). 職種 は,「技師」が 155 回答,「技師とシステム担当(医療 職)を兼任」が 17 回答,「技師とシステム担当(事務 職)」，「技師とリスクマネージャ」，「技師と事務職」, 「技師と教員」,「システム担当と医療職」がそれぞれ 1 回答であった。病床数は,「301-400 床」と「100 床以 下」が共に 29 回答で, 最も多かった (Fig. 2). 外来患 者数については, 外来なしの施設から 5000 件の施設 まで幅広く，平均 766 件 (中央值 600 件)であった。技
Table 1 Number of responses from each facility type

\begin{tabular}{lc}
\hline \hline \multicolumn{1}{c}{ Category } & Answer \\
\hline $\begin{array}{l}\text { Municipal hospital } \\
\text { (自治体で設立した病院) }\end{array}$ & 41 \\
$\begin{array}{l}\text { Medical corporation } \\
\text { (医療法人で設立した病院) }\end{array}$ & 38 \\
$\begin{array}{l}\text { University hospital } \\
\text { (医学部附属病院) }\end{array}$ & 27 \\
$\begin{array}{l}\text { Public hospital } \\
\text { (厚生連や赤十字などの病院) }\end{array}$ & 22 \\
$\begin{array}{l}\text { National hospital } \\
\text { (国立病院機構などの国立病院) }\end{array}$ & 15 \\
$\begin{array}{l}\text { Social insurance hospital } \\
\text { (社会保険関連の病院) }\end{array}$ \\
$\begin{array}{l}\text { Other } \\
\text { (その他) }\end{array}$ \\
\hline \multicolumn{2}{c}{ Total } \\
\hline
\end{tabular}

師数については, 平均值 19.1 人 (中央值 14 人), 1〜15 人が 96 回答, 16 30 人が 48 回答, 31 45 人が 22 回 答, 46 人 60 人と $61 \sim 75$ 人が 4 回答, $76 \sim 95$ 人が 3 回答であった。調査したモダリティのうち「computed radiography (CR, 一般撮影), mammography (MG, マンモグラフィ), computed tomography (CT, コンピュータ断層撮影), magnetic resonance imaging (MRI, 磁気共鳴撮像), interventional radiology (IVR, 血管造影), X-ray fluoroscopic(RF, 透視撮影), 


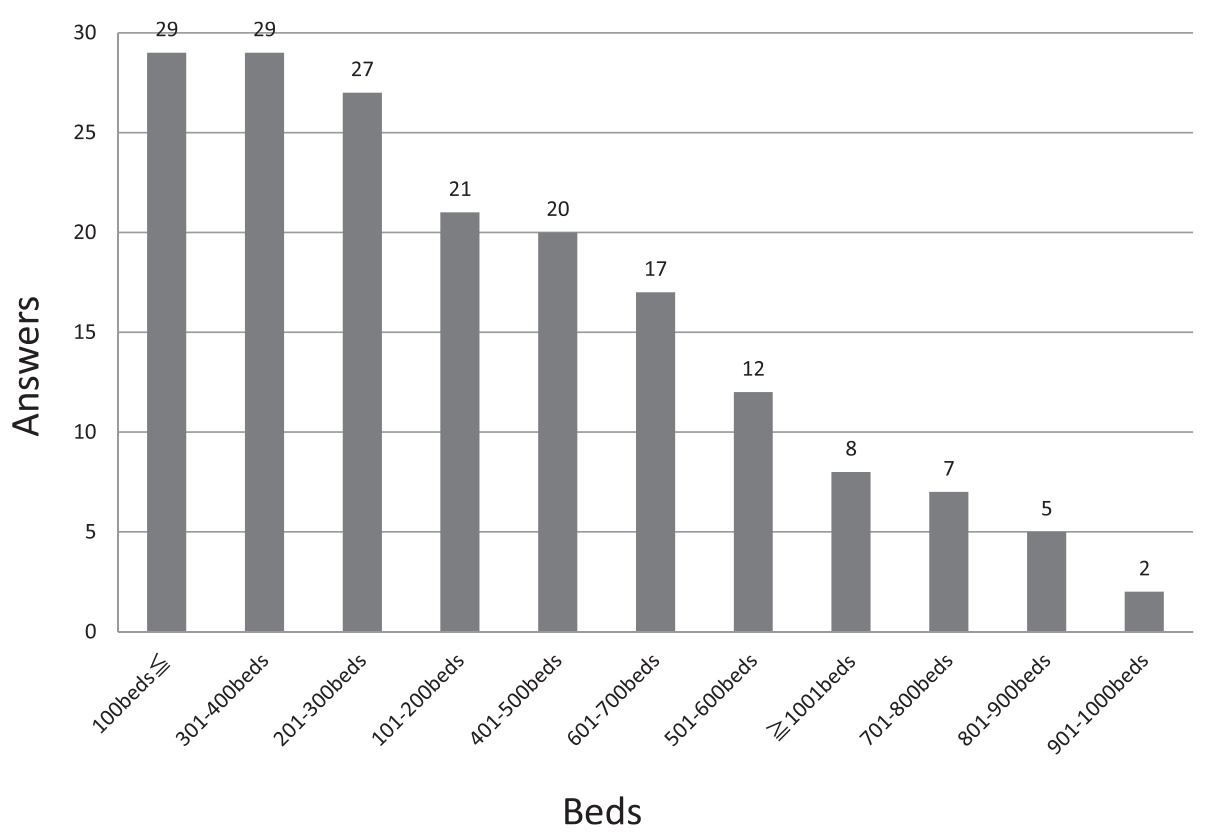

Fig. 2 The number of hospitals beds.

Table 2 Timing of the system introduction

\begin{tabular}{lrrrrrrrr}
\hline \hline Process of the purchase & X-ray & CT & MG & MRI & IVR & RF & NM & PET \\
\hline With modality & 21 & 10 & 12 & 8 & 5 & 3 & 3 & 3 \\
With PACS & 60 & 44 & 32 & 42 & 25 & 26 & 19 & 5 \\
Only Kenzo system & 6 & 4 & 3 & 3 & 1 & 3 & 3 & 1 \\
None & 0 & 2 & 0 & 3 & 3 & 0 & 0 & 0 \\
Other & 5 & 1 & 0 & 2 & 0 & 0 & 1 & 1 \\
\hline Total & 92 & 61 & 47 & 58 & 34 & 32 & 26 & 10 \\
\hline
\end{tabular}

nuclear medicine (NM, 核医学撮影), positron emission tomography (PET，陽電子放射断層撮影)」におい て，いずれかに検像システムを導入している施設は 117 回答であった。画像情報の確定に関するガイド ライン」(ガイドライン)を読んだことがあると回答し たのは 112 回答であった。

\section{2-2 フィルムレスの導入状況(質問 9，質問 10～12)}

各モダリティのフィルムレスの導入状況について有 効回答 177 のうち一般撮影が最も多く 121 回答, 続い てCT が 115 回答, MRI が 107 回答, RF が 103 回答, IVR が 93 回答, MG が 89 回答, NM が 80 回答, PET が 28 回答であった。検像システムを利用して検像行 為を行っている施設 117 回答をモダリティ種別で見る と, 一般撮影が最も多く 110 回答, CT が 81 回答, MRI が 76 回答, MG75 回答, RF が 67 回答, IVR が 49 回答, NM が50 回答, PET が 19 回答であった。 1 施設における「検像システムを採用しているモダリ ティ数」は, 調査した 8 モダリティすべてに導入して
いたのは 10 回答， 7 モダリティが 27 回答，6 モダリ ティが 9 回答, 5 モダリティが 16 回答, 4 モダリティ が 7 回答, 3 モダリティ 18 回答, 2 モダリティが 12 回 答, 1 モダリティのみが 18 回答であった.

\section{2-3 検像システム導入のきっかけ(質問 15)}

モダリティによらず「PACS 購入時」が最も多く, 一般撮影では有効回答 92 回答のうち 60 回答であっ た、「検像システムを単体で購入」していたのはわず か 6 回答であった。設問以外の回答には, radiology information system (RIS) 購入時, 施設の工事(移築な ど)が挙げられた(Table 2)。

\section{2-4 検像行為のタイミングと担当者について} (質問 16〜18)

ガイドラインで示された 3 ユースケース (Fig. 3)の うち, 本質問ではユースケース 2 を対象とした。般撮 影では有効回答 92 のうち 83 回答, CT では有効回答 61 のうち 48 回答がユースケース 2 であった (Fig. 4). 


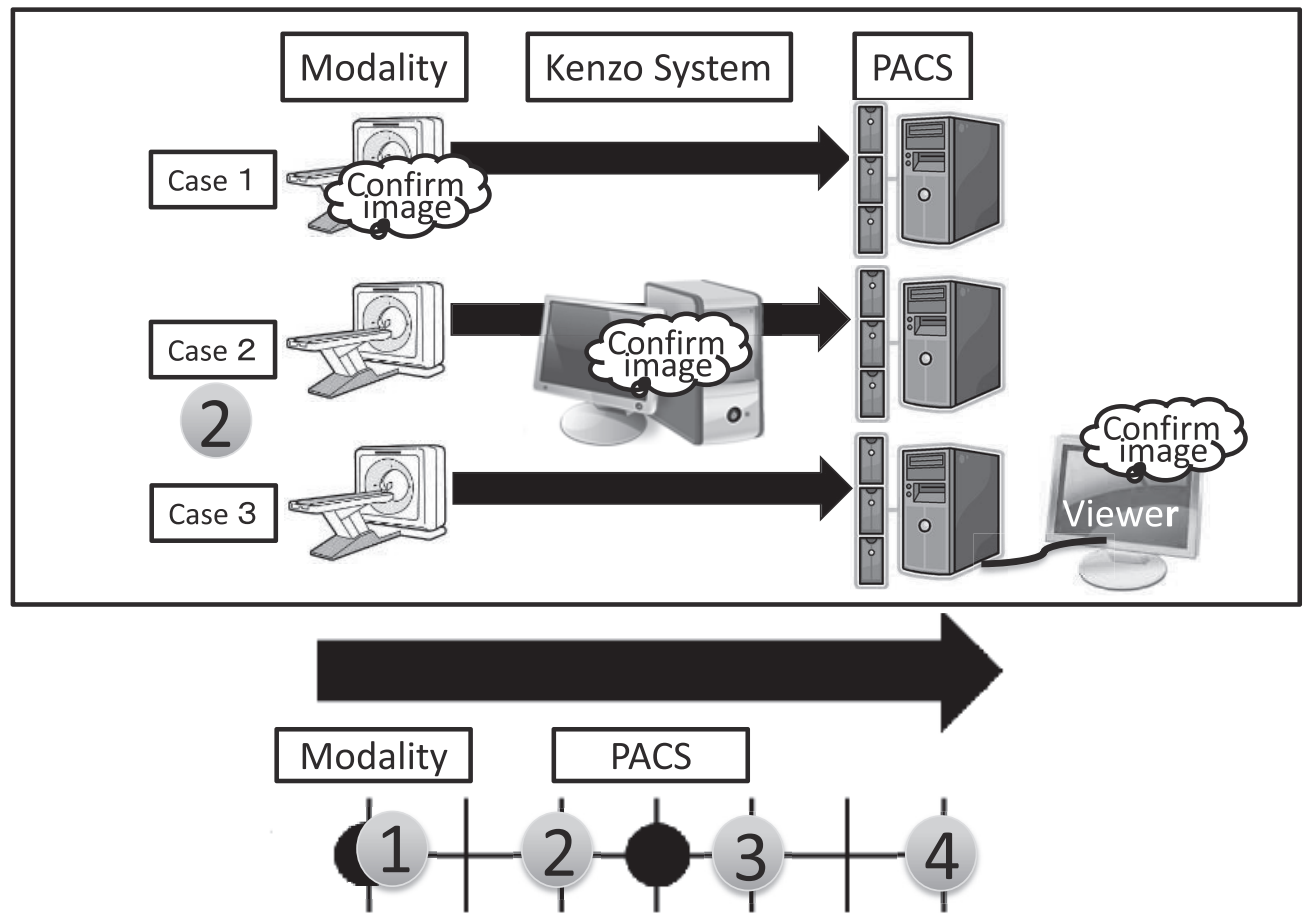

This study focuses on a facility that incorporates Kenzo system. Question 16 pertains to the "timing of confirmed images." One of the answering options provided was "QA can be ensured by displaying an image of the modality." However, several of these answers may include facilities where system A has not been introduced. Therefore, in the proposed study, such answers have not been taken into consideration during analysis.

Fig. 3 Timing of confirmed image (KAKUTEI).

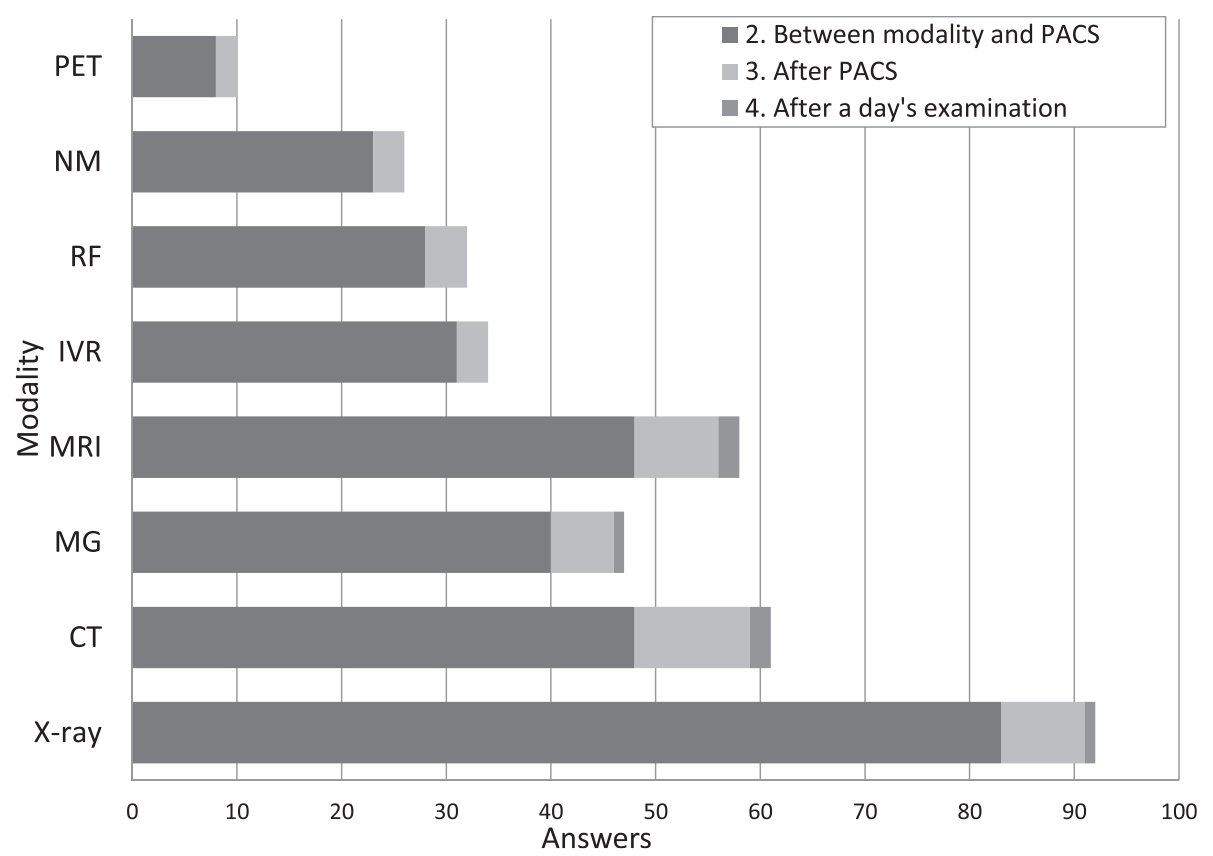

Fig. 4 Timing to confirm the image for each modality.

どのモダリティでも約 $80 \%$ 以上の回答がユースケー ス 2 であり, IVR が最も多く34 回答のうち 31 回答で あった. 検像行為を行う担当者 (専任者)について Fig. 5 に示す。どのモダリティでも，「撮影者が検像行為を
行っている」との回答が一番多かった。「撮影者以外 が行っている」, 「責任者(常勤, 役職者など), 早番・準 夜勤者が行っている」などがあった，検像行為に対す る専任者の経験年数については，「5 年以上の技師歴」 


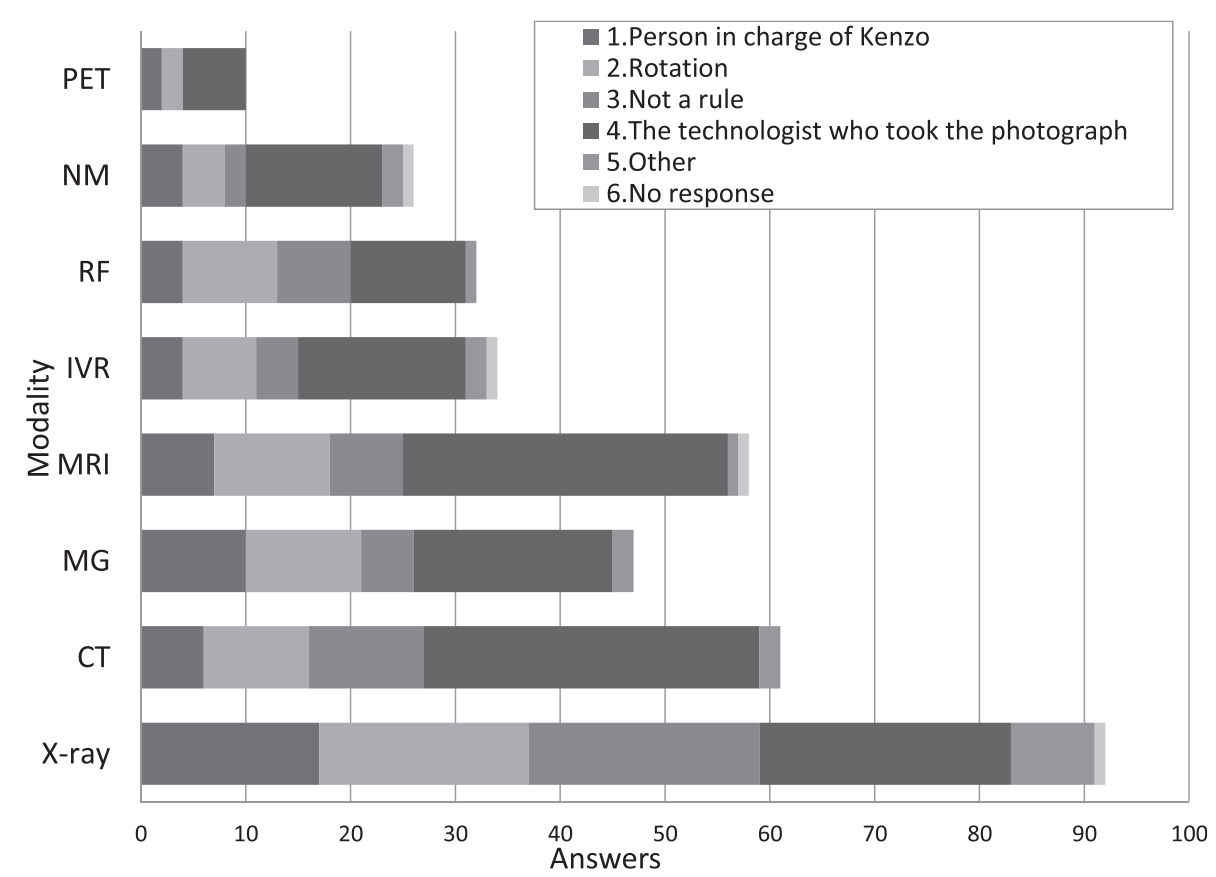

Fig. 5 Rules to decide "person responsible for confirming images (KAKUTEI)".

Table 3 Years of service by the radiological technologist who performed Kenzo system

\begin{tabular}{lrrrrrrrr}
\hline \hline Process of the purchase & X-ray & CT & MG & MRI & IVR & RF & NM & PET \\
\hline Within 5 years & 0 & 0 & 0 & 0 & 0 & 0 & 3 & 0 \\
Over 5 years & 33 & 16 & 22 & 18 & 12 & 1 & 6 & 3 \\
Not a rule & 32 & 25 & 14 & 21 & 17 & 7 & 8 & 6 \\
Other & 2 & 0 & 0 & 2 & 1 & 0 & 3 & 0 \\
No response & 25 & 20 & 11 & 17 & 16 & 8 & 5 & 1 \\
\hline Total & 92 & 61 & 47 & 58 & 46 & 16 & 25 & 10 \\
\hline
\end{tabular}

と「特に決まっていない」に分かれた(Table 3).

\section{2-5＼cjkstart検像システムを導入時に新たに追加した機能・ 理由について}

回答から得られた「追加した機能や理由(導入の目

的）」は，大きく五つに分類することが可能であった．

(1)システム間の情報連携

Modality worklist managementを利用した検査 情報の連携，患者情報や検査情報の整合性を確認す る連携。

\section{(2) 情報処理の機能}

Digital imaging and communications in medicine (DICOM) 情報の編集（施設名や患者氏名など）, storage commitment (画像保存の責任明確化のた め), 画像の送信先サーバの選択, 自動 (滞留) 送信機 能，シリーズ番号などの自動付与.

(3) 画像処理，参照や表示に関する機能

過去画像との比較参照, 画像の並び替えや分割,
アノテーションの付加や修正

(4) 検像行為と確定者に関する情報の機能

画像情報の確定者名の登録や保存，検像行為の履 歴, RIS への履歴保存, 再撮影情報の保存と出力.

(5)その他

画像サーバへの未送信を防止するための情報管 理，医用画像表示用モ二夕 ${ }^{16)}$ の精度管理，線量情報 の管理(異常值の検出), 撮影方向の警告.

\section{2-6＼cjkstart導入済みの検像システムに関する問題点}

自由記載によって得た回答は，大きく三つに分類す ることが可能であった。

(1) 画像処理・送受信に関する問題

大量の検査や画像を送信する際に起こる処理速度 の遅延, 性能の低さ (サーバや操作端末), 画像方向 や拡大率を変更してPACS に保存することができ ない, 自動判別 (自動検像) 機能がない.

(2)操作性に関する問題 
階調処理や過去画像参照の操作性が悪い, 付带情 報を容易に確認できない, 削除画像が保存されない.

(3) 管理, 運用の問題

検像者(画像情報の確定者)の履歷を印刷や記録す ることができない，自動(滞留)送信を多用してい る, 特定モダリティのみに検像システムを利用して いる，人員数から専任者を用意できない.

\section{2-7 検像システムを導入しない，できない理由}

「画像送信量が多い場合，または複数モダリティか らの画像送信タイミングが重なる場合などに処理可能 な性能を持つサーバや操作端末を導入できるか」と いった処理遅延に対する不安,「検像システムでの作 業自体が作業時間を増加させる」との意見もあった。 他, 「診療報酬がない, 施設の理解がない, 高額, 費用 や人員を確保できない」などの回答であった。

\section{3. 考 察}

モダリテイ別のフィルムレス導入では，一般撮影の フィルムレス率が一番高かった。一般撮影は一度の撮 影に複数部位・方向・撮影法が混在する場合が多いた め, 撮影効率向上や患者の負担軽減を目的として撮影 順を決めることがある。一方で読影医師が正確で効率 よい安全な読影を行うため, PACSの viewerでは統 一した表示順になるよう求められる。これら課題を解 決するために, 検像システムの画像処理機能を利用し て並び替え等の修正を行っていると予測される。「導 入時に追加した機能」でも画像の並び替えが挙げられ ていたここの機能を導入する際には仕様書に「画像の 並び替えを手動，または自動で行える機能を有するこ と.シリーズや検査の分割や結合が可能であること」 など記載する ${ }^{4,5)}$. このほか, 患部の方向や角度などを 調整しながら行う撮影の場合, 過去画像との比較やア ノテーション (A-Pや $30^{\circ}$ など)を挿入する機能が必要 であるため, 状況に応じて記載するとよい ${ }^{4.516)}$ (Table 4). CT と MRIは，一般撮影に比べ取り扱う画像枚数 が多く, 複数メーカ装置から出力された画像を同一 PACS 内に保存し, 同一 viewer で表示順やレイアウ 卜を統一しなければならない，方法としてはPACS 側で調整することもできるが，検像システムにて自動 ソートや画像の並び替えなどの編集機能が有効であろ う。仕様書には, 既設の PACS とモダリティメーカ, ソフトゥェアのバージョンなどを明示したうえで,

「既存のシステム環境で送受信した画像が, PACS (viewer)で統一した表示となるような画像の並べ替 え機能を有すること, 自動または手動でシリーズ番号
を振り直す機能を有すること」など，施設に合わせて 記載する. 次に, 処理速度の遅延やサーバまたは操作 端末の処理能力不足など，ハードウエアの問題である が, これらの解決としては, 仕様書に 1 日の送信画像 量やピーク時の画像量などを記載することで, 施設環 境に合わせた機器の性能が見極められる。更にCTや MRにおいて，操作卓に設置されたモニタが，医師読 影用の医用画像表示用モニ占 ${ }^{17)}$ と異なる表示関数を 用いている場合は，医用画像表示用モニ夕の DICOM 規格 grayscale standard display function (GSDF) に調 整されたモニ夕を検像システムに採用すればよいと考 えられる ${ }^{18 \sim 21)}$. 更に仕様書には「検像システム用端末 には, DICOM 規格の GSDF に準拠した医用画像表示 用モニ夕を設置すること.」と記載するとよい $\left.{ }^{19}, 20\right)$ (Table 4). 医用画像表示用モニ夕は定期点検を行う ことにより品質を担保しなければならないため ${ }^{16)}$, 品 質管理のための定期点検 (保守契約)も含めて記載する のか検討が必要である。マンングラフィでは DICOM や精度中央管理委員会などの関連ガイドライン ${ }^{22,23)}$ を 示し記載する ${ }^{22 \sim 24)}$ (Table 4).

患者情報や撮影に関する付带情報の確認や修正に関 する機能については,「検像システムとRISまたは hospital information system(HIS) 間にて検査情報を連 携すること」,「検像システムの画面上に検査情報を表 示すること」，「付帯情報に誤りがある場合は，正しい 患者情報や検査情報が取得できること」など，要望す る機能を具体的に記載する。 この連携機能は検像シス テムと HIS 間での接続が発生するため, 接続費の確保 が必要である。予算が確保しやすいシステムの調達と 関連させるなど中長期的にスケジュールを検討し，接 続作業と費用を盛り込んで記載しておくとよい，上記 以外では, DICOM 情報の編集機能により施設名の統 一や患者氏名の整合性確認 (自動チェック機能), storage commitmentによる画像保存の通知機能など も記載するとよい ${ }^{25)}$. 検像システム導入のきっかけで $\lceil\mathrm{PACS}$ 購入時」が大半を占めていたが, PACS と画像 関連システムをまとめて購入しやすい，またはPACS の一部機能として購入する例が多いからと考える。ま た, PACS 購入時に画像関連の業務フローを見直し検 像システムを取り入れた可能性も考えられる。

検像行為の担当者は「撮影者が行う」との回答が一 番多かった。これは, 撮影者が撮影時の患者状態など を一番よく理解しているため, 画像の可否判断に適し ていると考えられる. 組織的な理由としては, 検像行 為の専任者を配置する人員が不足している, システム 設備(操作端末など)の不足などが挙げられた。一方で 
Table 4 The specifications of the function in introducing Kenzo system

\begin{tabular}{l}
\hline Purposes of the system \\
\hline \hline Examples \\
\hline Reduction of burden on patients; reduction in shooting \\
time and improvement in efficiency (患者の負担軽 \\
減や撮影時間の短縮による効率化) \\
• Prevention of misidentification of body parts and \\
inspection of contents; guaranteed medical safety (撮 \\
影部位や撮影情報の誤認を防止し医療安全を担 \\
保) \\
・ Presentation of appropriate image for diagnostic \\
reporting; creation of streamlined diagnostic report \\
(診断に適した画像提供による読影効率の向上) \\
・ Streamlining of the creation of interpretation report by \\
automation (自動システム化による, 作業効率の) \\
向上) \\
\hline
\end{tabular}

- Maintenance of the reproducibility of image to reduce the number of repetitive photographing operations again, thereby ensuring medical safety（画像の再現 性を保ち, 再撮影を低減することによる医療安全

\footnotetext{
- Management and reduction of exposure dose; reduction in the number of repetitive photographing operations（被ばく線量の管理と低減, 再撮影の低減）
}

- Monitoring of diagnostics for medical imaging with unified performance, thereby improving collateral for medical safety and image diagnostic efficiencies (読影環境 (表示)の統一による医療安全の担保と 読影効率の向上)

- Progress of quality of image diagnostic assistance by confirming image (検像行為による読影補助の品 質向上） の向上）

- During the image confirmation work, function to refer past images on the system（検像システム上で，撮影検査や当該患者の過去画像が参照 できること)

- Functions enabling enlargement or reduction of image to an arbitrary size and saving it in an arbitrary size（拡大や縮小機能を有し，任意の拡大ま たは縮小率で保存できること)

- Comparison with the "pre-set dose value" and showing of an alert in case of overdose or underdose (子女設定した線量值と比較し, 過剰または過 少の場合は警告を表示する)

- Functions to be able to perform sorting of images "manually or automatically”; functions to edit DICOM tag（手動または自動により，ソートや 並び替えなどの情報編集の機能があること）

- Functions to arrange images received from all modalities into a unified image layout meant for PACS (viewer).（どのモダリテイから受信した 画像でも, PACS (viewer)で統一した表示となるような画像の並べ替 え機能を有すること)

・ Function to give the series number automatically or manually（自動または 手動でシリーズ番号を振り直す機能を有すること）

(It is necessary to explain PACS, modality manufacturer, software version, etc.) (PACS やモダリテイのメーカ, ソフトウエアのバージョンなど を明記することが必要)

- For the clients (computers) that perform image confirmation, a monitor conforming to the DICOM standard GSDF should be attached. (検像シス テム用端末，または検像行為を行う箇所の端末には，DICOM 規格の GSDFに準拠する医用画像表示用モニタを設置すること）

- (Description of periodic expection and maintenance contract for quality control)（品質管理のための定期点検(保守契約)についての記載も考 慮)

- (In mammography), display the image according to the guidelines, introduce “○ M" medical image display monitor.（マンモグラフィでは)ガイドラ インに準拠した表示が可能であること，○Ｍの医用画像表示用モ二 夕を用意すること)

- Purchase of suitable hardware (server device, operation client) according to the diagnostic situation in facilities. Prevention of risks such as delays and interruption of work（施設環境に合わせた適切な ハードウエア(サーバや操作端末)を購入し, 業務 の遅延や停止などのリスクを防止)

- Planning and budgeting of long-term plan concerning hardware renewal (ハードウエアの更新に関する 長期計画の立案と予算組み)
- "Number of images per day, number of images at peak time, maximum number of images per examination" are described. (1 日の画像量, ピー ク時の画像量, 1 検査あたりの最大枚数などを記載する)

• (Other) Model, number of modality devices, number of expectations, average number of images per expectation, interval of images sent (minutes), sent frequency, etc. ((その他) 機種, モダリテイ機器数, 検査数, 1 検査あたりの平均の画像枚数, 画像の送信間隔(分), 送信頻度 な ど) 
Examples of functional requirements

Purposes of the system

- Prevention of patient mix-ups by ensuring consistency of patient information（患者情報の整合性確保によ る患者誤りの防止)

- Prevention of re-taking and errors by ensuring 情報の整合性確保による，再撮影や撮影誤りの防 止)

- Use automation and systems to improve work efficiency（自動化やシステム利用による，作業効率 の向上) consistency in the information of examinations (検査

Examples described in the specification

- Function to send and receive information on of examinations, between “Kenzo System” and RIS or HIS（検像システムと RIS または HIS 間に て検査情報を連携すること）

- Display information of examinations on the operation screen of "Kenzo system”（検像システムの画面上に検査情報を表示すること）

If there is an error in the examination or patient information, function to inquire the information server of patients and examinations using the patient ID as a key and to obtain correct information.（検査の付帯情報に誤りが ある場合は患者 ID をキーとして，患者情報や検査情報を保有する サーバに問い合わせを行い，正しい情報の取得ができること）

• Functions to correct patient's information manually or automatically（患者 情報を手動で修正することが可能であること)

- With the automatic editing function of DICOM information, it is possible to unify facility names and check consistency of patient names. (DICOM 情 報の編集機能により，施設名の統一や患者氏名の整合性確認(自動 チェック機能)ができること)

- Functions to enable saving of images by using Storage Commitment of DICOM（Storage Commitmentによる画像保存の通知ができること）

- Requirements that comply with laws and guidelines on electronic preservation（法令や電子保存に関する ガイドラインを遵守した要件の担保)

Clarifying the person responsible for creation (作成 責任者の明確化など)
- After confirming the image, function to ensure the image is not sent to PACS unless you select the name of the operator and press the confirm button of images（検像行為後は，検像を実施した者の氏名を選択した 後に確定ボ夕ンを押さなければPACS に画像が送信されないように すること)

- (When there is automatic transmission function) When the confirmation operation is not executed, the function to stop the sending of the examination for a certain time ((自動送信機能がある場合)検像行為が 未実施の場合，一定時間は検査の送信が保留される機能を有するこ と)

• Optionally, the function to set hold-time of the sending（送信保留時間を 任意に設定できること)

- Save the history $(\log )$ of the confirmation operation in "Kenzo system" or RIS（検像システムまたは RIS 内に, 検像行為の履歴情報を保存する こと)

- Save the name, date, and time concerning the confirmation operation (検像 行為を行った者の氏名や日時を保存すること)

- The saved information is outputted as a file such as CSV（保存した情報を CSV などで出力することができること）
は，撮影者以外が検像行為を行うことでダブルチェッ クを行っているとの回答が得られた．次に追加した機 能や導入システムの問題点において「誰が検像行為を 行ったか記録する機能が必要」である旨の回答が得ら れた。これらに関して,「検像システムにて, 画像の確 定者や時刻などを記録すること，操作履歴を保存する こと」など仕様書に記載するとよい. 確定者について は,「デイジタルデータや印刷により抽出ができるこ と，RISへ情報を送信すること」など記載する。これ らの情報は，業務評価や業務分析，医療安全などに利 活用が可能な情報である。これらの情報を保存する際 は，どのような情報をどう利用したいのかを明確にし てから設計することが重要である。

以上，いずれの機能も，患者の取り違え防止，再撮 影の管理, 業務の効率化, 撮影の再現性維持, 撮影ミ スの防止など，撮影にまつわる安全管理や品質保証，
業務の効率化である. システム導入を希望する場合 は,「自施設に必要な機能, 導入されることで得られる 効果」などを施設や組織に対して具体的に提示しなけ ればならない，医療安全面で考えると，「過去画像の 比較機能による再撮影の低減について予測数を示す, 患者情報や検査情報の連携機能による PACS デー夕 の削除や修正数の変化予測数を示す」など挙げられ る。また効率化の面では,「システム導入によって業 務が効率化された場合に発生する時間や作業量を試算 し，どのように別業務に利用するか」など，システム 導入により変化する一連を示すことで，他部門や施設 全体に対して効果や最適化に繋がる提案も可能であろ う，回答の中には，算定による増収がない，業務評価 を図る指標がないなどが挙げられた。 これらについて も,「医用画像の検像行為に検像システムを用いるこ とは施設にとって有益である」ことを示す指標や基準 
を業務分析により創出し，各施設が事例を広く発表し 共有することでエビデンスを示すことが必要である. 一方で,「システムを導入しなくとも検像行為が可能 である, 撮影件数が少ない, 検像システムを介して画 像を送信することによるスループットの低下（送信時 間の増加)」などの理由から, システム導入を行ってい ないとの意見もあった。法律やガイドラインを遵守し 「いつ，どこで，だれが，検像行為や確定操作を行った か」が施設内で明らかになっていれば，必ずしも検像 システムを導入する必要はなく, 運用管理規程を定め ることで問題ないと考えられる.

本研究の限界は, 施設の規模や放射線部門の技師 数, 画像や検査数により, システムに投資できる費用 が異なることである．伊藤 ${ }^{26)}$ は，「日本では医療機関 の設備投資に関する規制がないので, 電子カルテの導 入は各病院の意思決定によって決まる」としている. ここで難しいのは, 検像システム自体を導入するメ リットやその効果を, 他職種や経営者に対しどれだけ 説明できるかという点である. 今後, 具体的な検像シ ステムの導入効果を測定する指標や手法の検討が重要 である。

\section{4. 結 語}

アンケート調査の結果により得られた必要とされる
機能は，患者の取り違え防止，再撮影の管理，情報の 視認性向上等による業務の効率化, 撮影の再現性維持 などの安全管理や品質保証, 業務の効率化を目的とし たものであった。これらの結果を分析し，一般撮影， CT, MRI, マンモグラフィなどモダリティごとに検像 システムに必要な機能や仕様があることを明らかにし た、また，モダリティに限らず，検査情報や患者情報 などのシステム連携機能, 画像処理機能などの仕様書 への記載する機能要件を提案した。これらの結果は, システム導入を担当する技師が各施設の環境や要求に 合わせて具体的な仕様書の作成に用いることができ， システムの導入効果を測定する指標になりうると考え られる。

\section{謝 辞}

本研究は平成 25 年度日本放射線技術学会学術研究 班に採択され研究費の助成を受けた。

本研究の要旨は, 第 42 回日本放射線技術学会秋季 学術大会 (2014 年, 札幌市)にて発表した.

アンケートに際し，多くの日本放射線技術学会の会 員の皆様から回答をいただくことができた。ご協力く ださった皆様に心より感謝申し上げます。

\section{参考文献}

1）月刊新医療編, 電子カルテ \&PACS 白書 2013-2014 年版. 月刊新医療データブックシリーズ. エム・イー振興協会, 東京, 2013.

2）松田恵雄．診療放射線技師の視点から考える検像のあり 方. INNERVISION 2010; 25(11): 10-12.

3）神田幸助. 放射線技術と品質管理. 日放技学誌 $1984 ; 40$ (6): 945-961.

4）新田 勝, 櫛橋民生. モニ夕診断とその環境整備 検像シ ステム (画像データベース登録前の画像調整)の必要性. 臨床放射線 2005; 50(13): 1737-1742.

5）松田恵雄. 埼玉医科大学総合医療センターが考える検像 システム。日本放射線技術学会医療情報分科会雑誌 2008; 10: 59-68.

6）山田英司, 岸本健治, 久住謙一, 他. フィルムレス環境下 における一般撮影検像システムの構築一正確で迅速な新 しいワークフローの構築一. 日放技学誌 2011; 67(9): 1209-1215.

7）山田英司. モダリティ上での検像の問題点と検像システ ムの開発. INNERVISION 2010; 25(11): 28-30.

8）井原完有, 跡田直利, 永田実緒, 他. 検像の定義と病院シ ステムとの情報連携. 第 36 回日本放射線技術学会秋季学 術大会一般発表予稿集 2008; 64(9): 1095.

9）井原完有. 検像システムによる検像の実際一医用画像情 報のシステムによる管理と運用による管理とのバランス の重要性. INNERVISION 2010; 25(11): 25-27.
10）小笠原克彦. 医療情報分科会に求められているもの：第 30 回秋季学術大会 (松江) アンケート結果から. 日本放射 線技術学会医療情報分科会杂倠誌 2003; 1: 60-64.

11）隅田博臣. 医療情報分科会アンケート報告 (Opinions). 日本放射線技術学会医療情報分科会雑誌 2007; 8: 33-39.

12）梅田徳夫. 医療の情報化と分科会の発足. 日本放射線技 術学会医療情報分科会雑誌 2003; 1: 1-2.

13）日本放射線技術学会医療情報部会ホームページ. http:// www.jsrt.or.jp/97mi/.

14）(公) 日本放射線技術学会. 画像情報の確定に関するガイ ドライン第 2.1 版. 2013.

15) Public Interest Incorporated Association Japanese Society of Radiological Technology. Guideline for KAKUTEI of image information v. 2.12016.

16) 大塚昌彦, 中元 崇, 小西 勝, 他. 広島大学病院 (旧歯 学部附属病院)の歯科領域におけるフィルムレス化の経 験. 日放技学誌 2011; 67(6): 673-678.

17）(社) 日本画像医療システム工業会. 医用画像表示用モ二 タの品質管理に関するガイドライン. 2017. http://www.jiranet.or.jp/publishing/files/jesra/JESRA_X-0093B_2017.pdf.

18) National Electrical Manufacturers Association (NEMA). PS3.14 DICOM PS3.14 2018b-Grayscale Standard Display Function. http://dicom.nema.org/medical/dicom/current/output/ pdf/part14.pdf.

19) Samei E, Rowberg A, Avraham E, et al. Toward clinically 
relevant standardization of image quality. J Digit Imaging 2004; 17(4): 271-278

20）田中延和, 中健太郎, 末岡正輝, 他. 沉用液晶ディスプレ イモニ夕の臨床使用におけるグレースケール標準表示関 数の適用. 日放技学誌 2010; 66(1): 25-32.

21) Kimpe $T$, Tuytschaever $T$. Increasing the number of gray shades in medical display systems-how much is enough? J Digit Imaging 2007; 20(4): 422-432.

22）千葉陽子, 斎 政博, 坂本 博, 他. ソフトコピー診断に 扔ける検像システムの重要性の検討。日本放射線技術学 会東北部会雑誌 $2012 ; 21: 178-179$.
23）篠原範充. ディジタルマンモグラフィのための品質管理. 日放技学誌 2010; 66(3): 271-278.

24）堀田勝平. マンモグラフィ検診精度管理中央委員会によ るソフトコピー診断施設画像評価の開始について. INNERVISION 2012; 27(8): 2-6.

25）奥田保男. 検像の重要性について：ワークフローから見 た「検像」. 日本放射線技術学会医療情報分科会雑誌 2008; 10: 53-58

26）伊藤ゆかり. 医療機関での電子カルテ利用とその導入行 動. 医療と社会 2002; 12(3): 25-38. 